\title{
Phosphate desorption from soil in anion-exchange resin extraction
}

\author{
ERKKI AURA
}

Department of Agricultural Chemistry, University of Helsinki, 00710 Helsinki 71

\begin{abstract}
An attempt was made to clarify the mechanisms of phosphate desorption using the anion exchange resin method for extraction of phosphorus from soil. It was shown that there is a linear dependence between the amount of phosphorus desorbed and the square root of the desorption time. Through theoretical examination it was concluded that the above-mentioned relation between the desorption and time is a result of the diffusion of phosphate from porous soil medium. Using this interpretation of the desorption curve as a basis, the activation energy of the phosphate desorption was calculated from the experimental results obtained with resin extraction at different temperatures. The activation energy values were $32-64 \mathrm{~kJ} / \mathrm{mol}$ depending on soils involved. In application of the results, the mechanisms and rate at different steps of the desorption were examined.
\end{abstract}

\section{Introduction}

Pot experiments with oats (AURA 1978) indicated that the extraction of phosphorus from soil using anion-exchange resin and water seems to be a suitable method for measuring the phosphorus level of Finnish soils. Good results have been obtained earlier in other experiments (e.g. Cooke and HisLop 1963) using the resin method. The advantage of the resin method is apparently that the microstructure of the soil is not substantially changed by the extraction. When water acts as the extractant the sructure of the polymerous $\mathrm{Fe}$ - and $\mathrm{Al}$-oxide in soil scarcely changes as the phosphate is desorbed from the surfaces of the oxides. The aim of this study is to clarify the rapidity and mechanisms of the release of soil phosphate to a strong base anion exchange resin. The studies of the desorption of phosphate help us to understand the processes which occur near the root surface when the plant takes up phosphorus from soil.

\section{Desorption of phosphate from acid soil}

The polymerous A1- and Fe-oxides of soil are very porous substances. In an amorphous form their specific surface is over $100 \mathrm{~m}^{2} / \mathrm{g}$ (e.g. RAJAN et al. 1974, PARFitT et al. 1975). The diameter of amorphous oxide pores is very small. Probably only small molecules can move through them (PARFitT 1971). 
Apparently phosphorus on the surface of the pores is most easily released. This is the phosphorus which is extracted in the anion-exchange resin method. The strength of the bonding of phosphate on oxide surfaces is dependent on the stability of the bond between the phosphate oxygen and the central $\mathrm{Al}^{+++}$- or $\mathrm{Fe}^{+++}$-ion. Experiments made with gibbsite and goethite indicated that complete desorption of phosphate bound on these oxides is very difficult to obtain with dilute neutral salt solution (Hingston et al. 1974). There was less desorption from goethite than from gibbsite. Also, experiments made with soil indicate that it is difficult to obtain $100 \%$ desorption of the long term $\mathrm{P}^{32}$-exchangeable phosphate using $0.01 \mathrm{M} \mathrm{CaCl}_{2}$-solution (VAIDyanathan and NyE 1970). The slowness of the desorption is perhaps due to the phosphorus bound to two adjacent $\mathrm{Al}^{+++}$or $\mathrm{Fe}^{+++}$ions of oxide by two oxygen atoms thus forming a ring structure (Hingston et al. 1974). It should also be noted that iron is a transition metal while aluminium is not. For this reason phosphate oxygen as a ligand may form a stronger bond with iron than with aluminium.

The slow desorption of phosphate from aluminium and iron oxides can also be explained in another way. When a proton dissociates from the H- $\overline{\mathrm{O}}-\mathrm{P}-$ group of phosphate, the oxygen of the group has 3 unshared electron pairs. Water oxygen, $\underline{\overline{\mathrm{O}}}<\mathrm{H}_{\mathrm{H}}^{\mathrm{H}}$, has only 2 lone pairs of electron. Thus the phosphate can form a stronger bond with $\mathrm{Al}^{+++}$and $\mathrm{Fe}^{+++}$than water can. Phosphate oxygen has available for bonding the same number of electron pairs as has hydroxyl oxygen $\overline{\mathrm{O}}-\mathrm{H}$-. The hydroxyl group probably forms about as strong a bond with the aluminium and ferric ion as phosphate oxygen does.

Hingston et al. (1972) suggested that when phosphate is adsorbed onto $\mathrm{Al}$ - and $\mathrm{Fe}$-oxides, a proton at first dissociates from the $\mathrm{H}-\overline{\mathrm{O}}-\mathrm{P}$-group of the phosphate. This proton goes to the $\underline{\overline{0}}-\mathrm{H}$-group on the oxide surface, whereby an $\underline{\overline{\mathrm{O}}}<\underset{\mathrm{H}}{\mathrm{H}}$ group is formed which is readily displaced from $\mathrm{Al}{ }^{+++}$or $\mathrm{Fe}^{+++}$. The desorption reactions probably proceed in a reverse order. The phosphate oxygen, which is bound to aluminium or iron, takes a proton, thus facilitating its separation from the central ion. When the bond between phosphate oxygen and the central ion is broken, its place is taken by a water molecule whose oxygen attaches to the central ion. A proton can then be released from the water now bound, leaving the $\mathrm{OH}$-group attached to the central atom. It is possible that the proton attached to the phosphate oxygen has come from a water molecule which has first formed a hydrogen bond with the oxygen situated between the phosphorus and the $\mathrm{Al}^{+++}$(or $\mathrm{Fe}^{+++}$). The $\mathrm{OH}$-group thus formed can then become bound to the central ion in the place of the phosphate oxygen.

When a plant takes phosphorus from the soil, a determining factor in the process is the slow diffusion of phosphate in soil surrounding the root surface and root hairs (NYE and TINKER 1977). The cause of the low concentration of phosphate in the soil solution and its slow diffusion in the soil is the strong bonding of phosphate in iron and aluminium oxides. As the root of the plant takes up phosphorus, phosphate released from oxides is bound repeatedly while diffusing toward the root. The diffusion of phosphate is apparently 
very slow in the micropores of $\mathrm{Al}$ and $\mathrm{Fe}$ oxides. When phosphorus is extracted from the soil using anion-exchange resin, the diffusion of phosphate in the small pores is a factor which strongly affects the speed of extraction. The determination of the soil phosphorus condition using the resin method gives not only an indication of the amount of labile phosphorus in the soil, but also of the kinetic factor affecting the phosphorus uptake of the plant. If the factor which most of all limits the diffusion of phosphate is, indeed, the breaking off of phosphate oxygen from $\mathrm{Al}^{+++}$or $\mathrm{Fe}^{+++}$of oxides, the extraction of phosphorus from soil using anion exchange resin at different temperatures will give a picture of the activation energy of this step of the desorption.

\section{Experimental}

The characteristics of the experimental soils are shown in Table 1. The $\mathrm{pH}$ of the soils was measured in $0.01 \mathrm{M} \mathrm{CaCl}_{2}$-suspension (1:2.5). Organic carbon was analyzed by the wet combustion method (Graham 1948). The particle size distribution was determined by the mechanical soil analysis method of ELONEN (1971). Aluminium and iron were extracted by TAMm's acid ammonium oxalate solution. The ratio of soil to solution was 1 to 20 and the extraction time was two hours.

Table 1. Characteristics of experimental soils.

\begin{tabular}{|c|c|c|c|c|c|c|c|c|c|}
\hline \multirow{2}{*}{$\begin{array}{l}\text { Soil } \\
\text { No. }\end{array}$} & \multicolumn{4}{|c|}{ Particle size distribution, $\%$} & \multirow{2}{*}{$\mathrm{pH}$} & \multirow{2}{*}{$\begin{array}{c}\text { Org. C } \\
\% \text { of } \\
\text { DM }\end{array}$} & \multirow{2}{*}{$\begin{array}{c}\text { Water } \\
\text { extractable } \\
\text { P }(1: 40) \\
\text { mg/l of soil }\end{array}$} & \multicolumn{2}{|c|}{$\mathrm{mg} / \mathrm{kg}$ of soil } \\
\hline & $>200$ & $20-200$ & $2-20$ & $<2 \mu \mathrm{m}$ & & & & $\mathrm{Al}$ & $\mathrm{Fe}$ \\
\hline 1 & 27 & 61 & 5 & 7 & 4.7 & 1.0 & 24 & 2200 & 2380 \\
\hline 2 & 1 & 86 & 5 & 8 & 6.4 & 1.2 & 10 & 1900 & 2120 \\
\hline 3 & 1 & 84 & 7 & 8 & 5.8 & 2.3 & 6 & 1900 & 1440 \\
\hline 4 & 35 & 49 & 7 & 9 & 4.8 & 2.7 & 23 & 2350 & 2540 \\
\hline 5 & 4 & 68 & 16 & 12 & 5.3 & 1.8 & 8 & 2900 & 2800 \\
\hline 6 & 5 & 32 & 28 & 35 & 6.1 & 2.8 & 28 & 3100 & 6300 \\
\hline 7 & 1 & 29 & 31 & 39 & 6.2 & 5.2 & 5 & 3450 & 3200 \\
\hline 8 & 7 & 26 & 24 & 43 & 7.3 & 4.1 & 31 & 3550 & 7400 \\
\hline 9 & 38 & 14 & 13 & 35 & 5.9 & 2.9 & 10 & 7000 & 13000 \\
\hline 10 & 14 & 10 & 20 & 56 & 4.6 & 4.0 & 3 & 5900 & 13200 \\
\hline 11 & 6 & 8 & 15 & 71 & 4.9 & 3.2 & 5 & 4900 & 7500 \\
\hline
\end{tabular}

Phosphorus desorption experiments were made using the anion exchange resin method described earlier (AURA 1978). The ratio of anion exchange resin to soil, however, was greater than earlier so that the sorption of phosphorus into resin would not be a limiting factor in extraction. Figure 1 shows how the ratio of resin to soil affects the phosphorus desorption from soil. Based on these results, a ratio of $2 \mathrm{~g}$ resin (Dowex 21-K, 16-20 mesh, in chloride form) to $0.5 \mathrm{~g}$ of soil was chosen for soils containing small amounts of labile phosphorus ( $<10 \mathrm{mg} / \mathrm{l}$ water extractable $P$ ). When the soil for soils contained a great deal of labile phosphorus, $5 \mathrm{~g}$ of resin to $0.5 \mathrm{~g}$ soil was used. 
The volume of water in the extraction was $100 \mathrm{ml}$. A volume of $100 \mathrm{ml}$ of recovery solution $\left(0.25 \mathrm{M} \mathrm{Na}_{2} \mathrm{SO}_{4}\right)$ to $1 \mathrm{~g}$ of resin was used for the leaching of phosphate from resin.

Because of the high resin-soil ratio it was difficult to leach all of the phosphate from the resin with the sodium sulphate solution. For this reason it was necessary to make a correction graph for calculating the results. Into $100 \mathrm{ml}$ portions of water various amounts of phosphate were added and shaken for 1 hour with 2 or $5 \mathrm{~g}$ of resin. Leaching was done with 200 or $500 \mathrm{ml}$ of $\mathrm{Na}_{2} \mathrm{SO}_{4}$ solution respectively. The results are shown in Fig. 2. The graph pictured was used for correction of results.

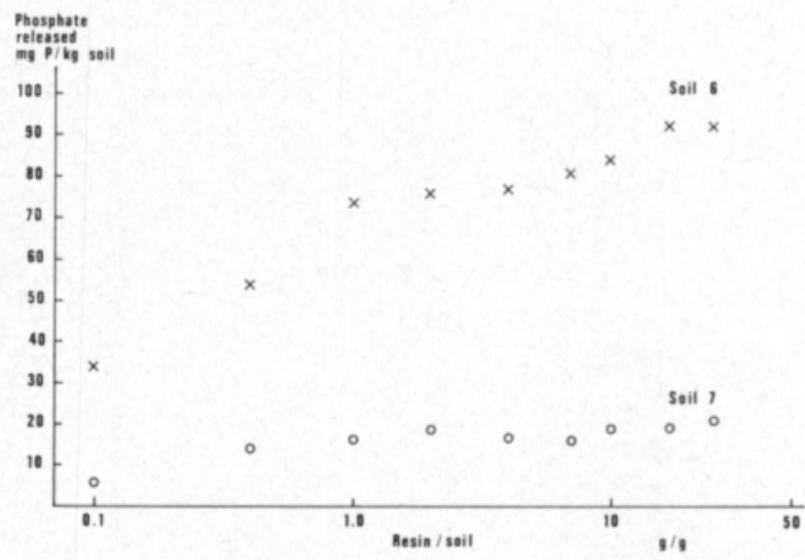

Fig. 1. The effect of resin-soil ratio on phosphorus extraction from soil. Extraction time 2 hours.

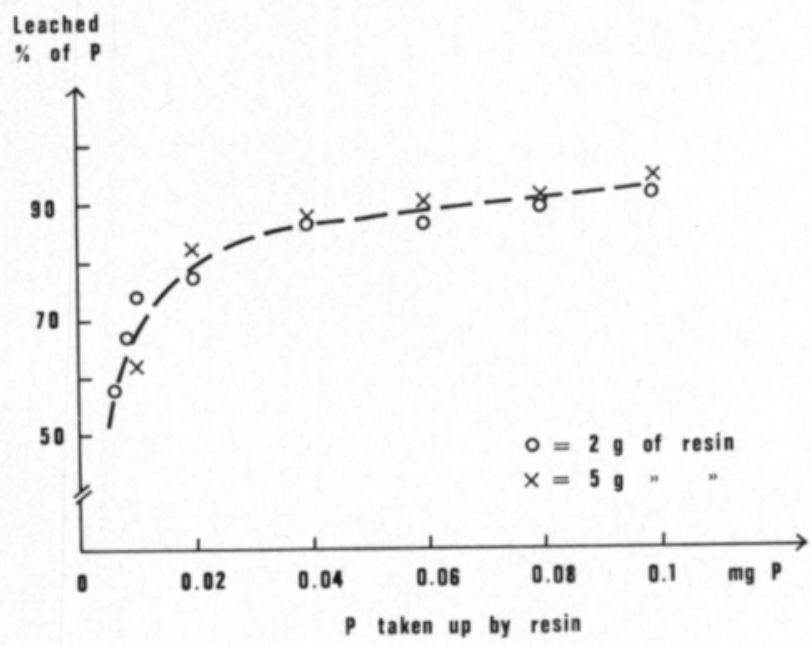

Fig. 2. Dependence of leaching results on amount of $\mathrm{P}$ adsorbed into resin.

The phosphorus concentration of the suspension water was also studied at various times during the resin extraction. Measurements of the P-concentration of the suspension water were made on soil 4 . This soil contained a great deal of sand and fine sand, so the filtration of the suspension (soil-resin-water) for phosphorus determination was rapid. Apparently there was scarcely any diffusion of phosphorus from soil particles during this short filtration time. 
According to the measurements the P-concentration of water during resin extraction was under $0.01 \mathrm{mg} / \mathrm{l}$.

For activation energy determination phosphorus was extracted from the soil by resin at temperatures of 4,10 and $20^{\circ} \mathrm{C}$. Results obtained in the 2 or 4 hour extraction were used to calculate the values of the activation energy.

\section{Dependence of phosphorus desorption on extraction time}

As Figures $3 \mathrm{a}$ and $3 \mathrm{~b}$ show, the amount of phosphorus desorbed from soil is in linear dependence on the square root of the extraction time. The desorption of phosphorus from soil 8 was no longer proportional to the square
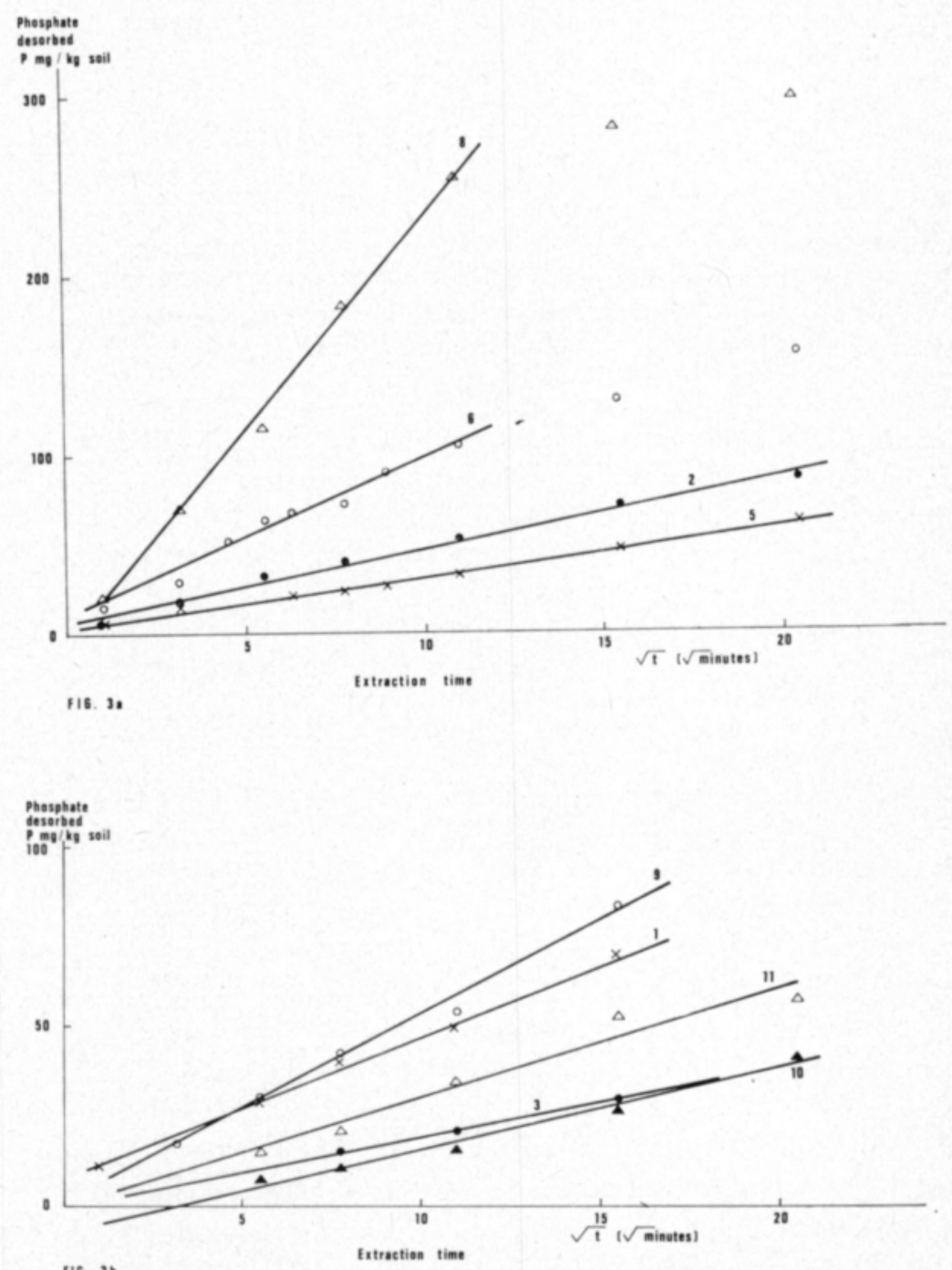

ค16. 36

Fig. $3 \mathrm{a}$ and $3 \mathrm{~b}$. The dependence of phosphorus desorption from soil on resin extraction time. 
root of the shaking time after 120 minutes. This soil contained a large amount of plant available phosphorus and $\mathrm{pH}$ was high, 7.3. The results seem to show that when the extraction time with the resin method is not very long the relation between the desorption and the square root of the shaking time can be expressed by a straight line. This type of dependence between the desorption and the extraction time when using the resin method was shown, for example, in the studies by Cooke (1966).

It is tempting to interpret the linear dependence between the desorption and the square root of the extraction time as resulting from the diffusion of phosphate from porous soil particles. In clay soils phosphorus diffuses from porous aggregates. Sandy soils are composed of primary particles, and therefore the phosphorus diffuses directly from porous $\mathrm{Al}$ and $\mathrm{Fe}$ oxide polymers into the surrounding suspension water. If the extraction time is not particularly long, phosphorus diffuses mainly from the porous surface layers of soil particles according to the following equation (CRANK 1970, p. 31):

$$
\mathrm{M}_{\mathrm{t}}=2 \mathrm{C}_{\mathrm{o}}\left(\frac{\mathrm{Dt}}{\pi}\right)^{1 / 2}
$$

where $\mathrm{M}_{\mathrm{t}}=$ the amount of phosphorus desorbed at time $\mathrm{t}$ from the unit area

$\mathrm{C}_{\mathrm{o}}=$ the original concentration of diffusible phosphorus in porous medium

$\mathrm{D}=$ the diffusion coefficient of phosphorus in porous soil medium

The concentration of phosphate in water outside the soil particles $\approx \mathrm{O}$

The $\mathrm{C}_{\mathrm{o}}$ and $\mathrm{D}$ of different soil particles vary. Phosphorus diffuses out of $\mathrm{n}$ different kinds of surface layers. Corresponding surface areas can be written in the following way: $A_{1}, A_{2}, \ldots, A_{n}$. In time $t$ the phosphorus diffuses from the soil as follows:

$\mathrm{Q}=2\left(\frac{\mathrm{t}}{\pi}\right)^{1 / 2}\left(\mathrm{~A}_{1} \mathrm{C}_{\mathrm{o} 1} \mathrm{D}_{1}{ }^{1 / 2}+\mathrm{A}_{2} \mathrm{C}_{\mathrm{o} 2} \mathrm{D}_{2}{ }^{1 / 2}+\ldots+\mathrm{A}_{\mathrm{n}} \mathrm{C}_{\mathrm{on}} \mathrm{D}_{\mathrm{n}}{ }^{1 / 2}\right)$

where $\mathrm{C}_{\mathrm{o}}, \ldots, \mathrm{C}_{\mathrm{on}}$ and $\mathrm{D}_{1}, \ldots, \mathrm{D}_{\mathrm{n}}$ are the original diffusible phosphorus concentrations and diffusion coeffisients corresponding to the particle surfaces $1, \ldots, n$. The value of the diffusion coefficient is dependent on the concentration of labile phosphorus in the porous material. However, in order to simplify the examination the coefficient D is held constant.

The diffusion coefficient of phosphorus in moist soils not containing high amounts of labile phosphorus is in the magnitude oi $10^{-9} \mathrm{~cm}^{2} / \mathrm{s}$ (GrahamBRYCE 1963, Lewis and QUIRK 1967, Kunishi and TAYLOR 1975). In micro aggregates which do not contain large pores the diffusion of phosphorus is apparently much slower than in a soil of normal structure. In sand soil or in dispersed clay soil the diffusion of phosphorus in particles is apparently extremely slow, since in these soils phosphorus diffuses during the resin extraction mainly from polymerous $\mathrm{Al}$ and $\mathrm{Fe}$ oxides. When the pore size in these oxides is about the size of small molecules (PARFITT 171), the diffussion of phosphorus in $\mathrm{Al}$ and $\mathrm{Fe}$ oxide pores is probably almost as slow as the diffusion in solid material. 
When the concentration of the desorbing substance outside the surface of the porous medium is zero the following equation holds (CRANK 1970, p. 30):

$$
\frac{\mathrm{C}}{\mathrm{C}_{\mathrm{o}}}=\operatorname{erf} \frac{\mathrm{x}}{2(\mathrm{Dt})^{1 / 2}}
$$

where $\mathrm{C}=$ the concentration of the substance desorbiong in the porous medium at time $\mathrm{t}$ at a distance of $\mathrm{x}$ from the surface

$\mathrm{C}_{\mathrm{o}}=$ the original concentration of the substance in the porous medium

A graph drawn according to the equation (3) is in Figure 4. It shows how the distance $\mathrm{x}$ from the surface of a porous medium is dependent on the diffusion coefficient $\mathrm{D}$. Thus $\mathrm{C} / \mathrm{C}_{\mathrm{o}}$ has a value of 0.90 or the concentration of

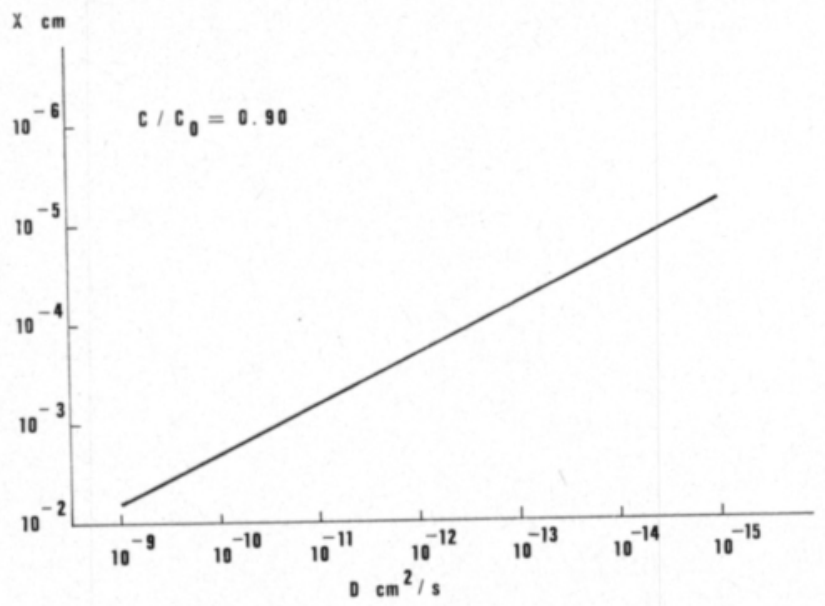

Fig. 4. The effect of diffusion coefficient on the desorption rate from soil particles. The symbol $\mathrm{x}$ indicates the distance from the surface of the particles at which $10 \%$ of the diffusible phosphorus has desorbed in 2 hours.

diffusible phosphorus at the distance $\mathrm{x}$ has decreased by $10 \%$ during time $\mathrm{t}$. The time t has a value of $7200 \mathrm{~s}$ (or 2 hours). The facts already stated and Figure 4 support the hypothesis that during short extraction times with the anion exchange resin, phosphorus is diffused from only the surface layers of porous soil particles, and therefore the equation (2) can be applied to the examination of the desorption of phosphorus from soil.

\section{Dependence of phosphorus desorption on temperature}

\section{a. Desorpation measurements at different temperatures}

If the phosphate diffusing from soil does not become bound to $\mathrm{Al}$ and $\mathrm{Fe}$ oxides on the pore surfaces, the value of the diffusion coefficient would depend only slightly on the temperature (NoBeL 1970, p. 101). Thus, according to the equation (1), the effect of the temperature on phosphorus desorption would be minimal. However, the desorption of phosphorus from soil in resin extraction is greatly dependent on the temperature, as shown in Table 2.

Desorption in these experiments did not show as great a dependence on the temperature as did the studies of COOKE and Hislop (1963), which showed that a rise in temperature from $10^{\circ} \mathrm{C}$ to $20^{\circ} \mathrm{C}$ increased the phosphorus desorption from soil by $1.5-2.2$ times. However, the extraction time in the 
experiments of COOKE and Hislop was long, 16 hours. The results obtained with resin indicate that the beneficial effect of temperature on the phosphorus uptake by plants which was observed in various studies (Sutton 1969, SIPITANOS and ULRICH 1971) is based partly on the chemical properties of soil. Table 2 also gives reason to suppose that the higher the soil $\mathrm{pH}$ and the less phosphate-binding $\mathrm{Al}$ and $\mathrm{Fe}$ oxides there are in the soil, the less dependent the desorption is on the temperature. However, this could be determined with more test material.

Table 2. Increase in desorption at rise in temperature from $10^{\circ} \mathrm{C}$ to $20^{\circ} \mathrm{C}$. Extraction time 2 hours.

\begin{tabular}{rrrrrr}
\hline Soil No. & $20^{\circ} \mathrm{C} / 10^{\circ} \mathrm{C}$ & $\begin{array}{c}\text { Desorbed } \mathrm{P} \\
\text { at } 20^{\circ} \mathrm{C} \\
\mathrm{mg} / \mathrm{kg} \text { soil }\end{array}$ & $\mathrm{pH}$ & \multicolumn{2}{c}{$\begin{array}{c}\text { Al and Fe extracted by } \\
\text { TAMM's solution mg/kg }\end{array}$} \\
\cline { 5 - 6 } & 1.6 & 33 & 4.9 & 4900 & $\mathrm{Fe}$ \\
\hline 9 & 1.5 & 59 & 5.9 & 7000 & 13000 \\
10 & 1.5 & 18 & 4.6 & 5900 & 13200 \\
1 & 1.5 & 51 & 4.7 & 2200 & 2380 \\
3 & 1.4 & 21 & 5.8 & 1900 & 1440 \\
8 & 1.3 & 254 & 7.3 & 3550 & 7400 \\
2 & 1.3 & 52 & 6.4 & 1900 & 2120 \\
\hline
\end{tabular}

\section{b. Energy of activation}

On the basis of the experiments conducted at different temperatures a calculation of the activation energy for the desorption was made. The relation between the value of the diffusion coefficient and the temperature is given by

$$
\mathrm{D}=\mathrm{D}_{\mathrm{o}} \mathrm{e}^{-\mathrm{E}_{\mathrm{a}} / \mathrm{RT}}
$$

where $\mathrm{D}_{\mathrm{o}}=$ constant

$\mathrm{E}_{\mathrm{a}}=$ activation energy $\mathrm{J} / \mathrm{mol}$

$\mathrm{R}=$ gas constant $8.314 \mathrm{~J} / \mathrm{mol}^{\circ} \mathrm{K}$

$\mathrm{T}=$ absolute temperature ${ }^{\circ} \mathrm{K}$

Since a kind of average value for $\mathrm{E}_{\mathrm{a}}$ is sufficient in these calculations, combining the equations (2) and (4) we get:

$$
\mathrm{Q}=2\left(\frac{\mathrm{t}}{\pi}\right)^{1 / 2} \mathrm{e}^{-\mathrm{E}_{\mathrm{a}} / 2 \mathrm{RT}}\left(\mathrm{A}_{1} \mathrm{C}_{\mathrm{o} 1} \mathrm{D}_{\mathrm{ol}}{ }^{1 / 2}+\ldots+\mathrm{A}_{\mathrm{n}} \mathrm{C}_{\text {on }} \mathrm{D}_{\mathrm{on}}{ }^{1 / 2}\right)
$$

As the shaking time, $t$, is constant and since the value in the parenthesis is not dependent on the temperature, by introducing the value of $\mathrm{R}$ we get:

$$
\log Q=-\frac{E_{a}}{38.28} \frac{1}{T}+\text { constant }
$$

The amount of desorbed phosphorus $Q$ was measured at temperatures of $4^{\circ} \mathrm{C}, 10^{\circ} \mathrm{C}$ and $20^{\circ} \mathrm{C}$. The activation energy Ea was obtained by graphical method in the ordinary way (e.g. MorRIs 1974, p. 269). The activation energies for experimental soils are shown in Table 3 . 
Table 3. Activation energies for phosphate desorption from soil.

\begin{tabular}{cc}
\hline Soil No. & $\begin{array}{c}\text { Activation energy } \\
\mathrm{kJ} / \mathrm{mol}\end{array}$ \\
\hline 11 & 64 \\
9 & 57 \\
10 & 55 \\
1 & 54 \\
3 & 50 \\
8 & 34 \\
2 & 32 \\
\hline
\end{tabular}

\section{Discussion}

The significance of the calculated activation energy may be interpreted in the following way. As phosphorus diffuses from soil particles, phosphate is repeatedly bound to $\mathrm{Al}$ and $\mathrm{Fe}$ oxides. The step which determines the rate of diffusion is mainly the detachment of phosphate oxygen atom from $\mathrm{Al}^{+++}$or $\mathrm{Fe}^{+++}$. If the detachment of phosphate oxygen is preceded by its acceptance of a proton, this step of the reaction is apparently rapid. When the phosphate oxygen takes a proton the coordination bond of the phosphate oxygen becomes as weak as that of the coordination water. The phosphate oxygen must move away a certain distance from the central ion before the oxygen of water or of hydroxyl can take its place. The energy required for this movement from the central ion is probably indicated by the measured value of $\mathrm{E}_{\mathrm{a}}$. For the sake of comparison, the activation energy required when a coordinated water molecule of $\mathrm{Fe}^{+++}$exchanges for another water molecule is about 60 $\mathrm{kJ} / \mathrm{mol}$ (BAsolo and PeArson 1967, p. 152). The exchange of coordinated water for water in solution occurs rapidly. The first order rate constant for the removal of water molecule from coordination sphere of $\mathrm{Fe}^{+++}$is about $10^{4} \mathrm{~s}^{-1}$ (Connick and Stover 1961). Activation energy does not appear to be so high that it would be the main cause for the slowness of phosphate desorption. Another factor probably retarding phosphate desorption is that perhaps only a small part of the phosphate oxygen bound on oxides has taken the proton which weakens the bond between phosphate oxygen and the central ion and makes desorption possible. Also, the desorption may be retarded due to the fact that phosphate can be bound to two adjacent contral ions in the oxide forming the ring sturcture. For desorption to occur in this case the two oxygens of the phosphate must become removed from $\mathrm{Al}^{+++}$or $\mathrm{Fe}^{+++}$ at the same time. In acid soil where phosphate is mainly in the $\mathrm{H}_{2} \mathrm{PO}_{4^{-}}$form, the ring structure of diffusing phosphate is improbable. The diffusing phosphate has not got time to form the ring structure. In the studies of RAJAN (1978), the rate of the ring formation of $\mathrm{H}_{2} \mathrm{PO}_{4}^{-}$on hydrous alumina was slow. Even after 6 days the percentage of $\mathrm{H}_{2} \mathrm{PO}_{4}^{-}$adsorbed that formed a ring structure was less than $15 \%$.

Acknowledgement. The author wishes to thank Kemira Oy:n Tutkimussäätiö for financial aid for this study. 


\section{REFERENCES}

AUrA, E. 1978. Determination of available soil phoshorus by chemical methods. J. Scient. Agric. Soc. Finl. 50: 305-316.

Basolo, F. \& Pearson, R. G. 1967. Mechanisms of inorganic reactions. 670 p. New York.

Connick, R. E. \& Stover, E. D. 1961. Rate of elimination of water molecules from the first coordination sphere of paramagnetic cations as detected by nuclear magnetic resonance measurements of $0^{17}$. J. Phys. Chem. 65: 2075-2077.

CоокE, I. J. 1966. A kinetic approach to the description of soil phosphate status. J. Soil Sci. 17: $56-64$.

- \& Hislop, J. 1963. Use of anion -exchange resin for the assessment of available soil phosphate. Soil Sci. 96: 308-312.

Crank, J. 1970. The mathematics of diffusion. 347 p. Oxford.

Elonen, P. 1971. Particle-size analysis of soil. Acta Agr. Fenn. 122: 1-122.

Graham, E. R. 1948. Determination of soil organic matter by means of a photoelectric colorimeter. Soil Sci. 65: 181-183.

Graham-Bryce, I. J. 1963. Self-diffusion of ions in soil. II. Anions. J. Soil Sci. 14: 195-200.

Hingston, F. J., Posner, A. M. \& Quirk, J. P. 1972. Anion adsorption by goethite and gibbsite. I. The role of the proton in determining adsorption envelopes. J. Soil Sci. 23: $177-192$.

- , Posner, A. M. \& Quirk, J. P. 174. Anion adsorption by goethite and gibbsite. II. Desorption of anions from hydrous oxide surfaces. J. Soil Sci. 25: 16-26.

Kunishi, H. M. \& TAYlor, A. W. 1975. The effect of phosphate applications on the diffusion coefficients and available phosphate in an acid soil. J. Soil Sci. 26: 267-277.

Lewis, D. G. \& Quirk, J. P. 1967. Phosphate diffusion in soil and uptake by plants. I. Selfdiffusion of phosphate in soils. Plant and Soil 26: 99-118.

Morris, J. G. 1974. A biologist's physical chemistry. 390 p. London.

Noвel, P. S. 1970. Plant cell physiology. 255 p. San Francisco.

NYE, P. H. \& TINKER, P. B. 1977. Solute movement in the soil root system. 342 p. Oxford.

PARfitT, G. D. 1971. Introductory lecture. Discussions of Fraday Soc. 52: 9-13.

Parfitt, R. L., Atkinson, R. J. \& Smart, R. C. 1975. The mechanisms of phosphate fixation by iron oxides. Soil Sci. Soc. Amer. Proc. 39: 837-841.

RaJAN, S. S. S. 1978. Sulfate adsorbed on hydrous alumina, ligands displaced, and changes in surface charge. Soil Sci. Soc. Amer. Proc. 42: 39-44.

- , Perrotr, K. W. \& Saunders, W. M. H. 1974. Identification of phosphate-reactive sites of hydrous alumina from proton consumption during phosphate adsorption at constant $\mathrm{pH}$ values. J. Soil Sci. 25: 438-447.

Sipitanos, K. M. \& UlRich, H. A. 1971. The influence of root zone temperature on phosphorus nutrition of sugarbeet seedling. J. Amer. Soc. Sugar Beet Technol. 16: 408-421.

Sutron, C. D. 1969. Effect of low soil temperature on phosphate nutrition of plants - a review. J. Sci. Fd Agric. 20: 1-3.

Vaidyanathan, L. V. \& NyE, P. H. 1970. The measurement and mechanism of ion diffusion in soils. VI. The effect of concentration and moisture content on the counterdiffusion of soil phosphate against chloride ion. J. Soil Sci. 21: 15-27.

Ms received September 11, 1978. 


\section{Fosfaatin desorptio maasta anioninvaihtajauutossa}

\section{ERKKI AURA}

Helsingin yliopiston maanviljelyskemian laitos, 00710 Helsinki 71

Käyttäen anioninvaihtajaa fosfaatin uuttoon maasta pyrittiin selvittämään fosfaatin desorption nopeutta ja mekanismeja. Tulokset osoittivat, että maasta vapautuneen fosforin määrä riippuu lineaarisesti uuttoajan nelijöuuresta. Teoreettisen tarkastelun avulla pääteltiin, että mainittu desorption ja uuttoajan välinen vuorosuhde on seurausta fosfaatin diffundoitumisesta pois huokoisesta maa-aineksesta. Nojautuen tällaiseen desorptiokäyrän tulkintaan laskettiin fosfaatin desorptiolle aktivoitumisenergia tuloksista, jotka oli saatu anioninvaihtajauutoissa eri lämpötiloissa. Aktivoitumisenergian arvoksi tuli maasta riippuen $32-64 \mathrm{~kJ} /$ mooli. Soveltaen saatuja tuloksia tarkasteltiin desorption eri vaiheiden nopeutta ja mekanismeja. 